the prevalence of immunity in the population by a survey of the influenza antibody titres over a wide range of age groups. In the present investigation these titres have been estimated in samples of serum from a large number of individuals of various ages in five areas of England.

More than 1,700 sera were tested, but the numbers of samples from most of the age groups were rather limited. A more selective investigation in additional areas would be necessary to confirm that the results obtained were truly representative of the titres in the general population. However, the results give a general indication of the proportion of persons with antibody in many areas in England.

The strain-specific complement-fixation test was found in practice to be very suitable for a survey of this kind, since it is simple and quick with a clearly recognizable end-point.

A previous investigation (to be published) showed that infection with influenza $A_{2}$ virus was followed by the production of antibody which could be detected equally well by the haemagglutination inhibition, serum neutralization, and strainspecific complement-fixation test and which persisted for at least nine years. In a few instances the complement-fixing and haemagglutination-inhibiting antibody had declined to a low titre by this time and occasionally even became undetectable, whereas neutralizing antibody could be demonstrated convincingly on all occasions. On this basis the results obtained by the present complement-fixation tests must be regarded as providing a modest estimate of the proportion of the population that possess antibody.

If, as seems probable, the presence of circulating antibody is accepted as indicating some degree of resistance to influenza, the findings clearly indicate that a substantial proportion of each age group in England is protected against the current strains of influenza virus. It follows, therefore, that until the antigenicity of the influenza strains is altered a widespread epidemic of influenza is unlikely in England.

The investigation demonstrated the heterogeneity of antibody to the influenza $A_{2}$ strains because antibody to one strain may appear after infection with another. This is evident from the findings in children under 5 years old. In this group most of those with antibody to the $A_{2} /$ England/129/66 strain also had antibody to the $A_{2} /$ Singapore $/ 1 / 57$ strain, though the children could not have been infected with the $A_{2} /$ Singapore/ $1 / 57$ strain, because it had disappeared from England before many of them were born; moreover, most of them were too old for maternal antibody to the $A_{2} /$ Singapore $/ 1 / 57$ strain to have persisted.

\section{Summary}

To obtain information on the susceptibility of communities to influenza viruses serum samples from 1,783 persons of all ages living in five different areas of England were examined. Strain-specific complement-fixation tests for antibody to influenza viruses were used.

The results indicated that antibody to both early and late antigenic variants of influenza $A_{2}$ virus and to influenza $B$ virus is widespread in all age groups. An epidemic due to the current strains is unlikely.

The strain-specific complement-fixation test was found to be highly suitable for this type of investigation.

We are grateful to Drs. B. Moore, C. E. D. Taylor, J. O'H. Tobin, and J. E. M. Whitehead, from the public health laboratories of Exeter, London, Manchester, and Coventry respectively, for sending us serum samples, and to Dr. T. Skeoch and Mr. H. Bell, of the Central Clinical Laboratory, Middlesbrough, for their help. We would like to thank two visiting workers from New Zealand, Dr. Jack Burton and Miss Marjorie Bennett, for their part in this investigation.

\section{REFERENCES}

Henle, W., Lief, F. S., and Fabiyi, A. (1958). Lancet, 1, 818.

Lief, F. S., and Henle, W. (1956). Virology, 2, 772.

Pereira, H., G., Pereira, M. S., and Law, V. G.' (1964). Bull. Wld Hlth Org., 31, 129.

\title{
Antibodies in Children's Sera for Serologically Different Recently Isolated Strains of Influenza Viruses $A_{2}$ and $B$
}

\author{
G. C. SCHILD,* B.SC., PH.D. ; C. H. STUART-HARRIS, † C.B.E., M.D., F.R.C.P.
}

Brit. med. F., 1967, 4, 82-84

The natural antigenic variation of the influenza viruses and its probable significance in relation to the sequence of epidemics and pandemics of human influenza is well known. In the case of the influenza $A, A_{1}$, and $A_{2}$ viruses the variation from one major antigenic form to another has occurred every ten or more years, but in between these happenings there have been minor variations with a progressive deviation from the prototype. In the case of the influenza $B$ viruses it has not proved possible to group strains into families arranged in a chronological sequence of occurrence as with influenza $A$ viruses, and the variation appears to have been relatively haphazard. The serological impact of the various races of both influenza $A$ and $B$ on the population has been studied by many workers. Davenport et al. (1953) were the first to show that different age-cohorts of the population exhibit different serological spectra against the major influenza A virus families. They attributed their findings to a dominating influence on the

* Department of Bacteriology, University of Sheffield.

t Department of Medicine, University of Sheffield. immunological mechanism of childhood infection by the particular virus serotype then prevalent. Reinforcement of this antibody production by subsequent exposure to other serotypes occurs during adult life. Their doctrine of " original antigenic sin" or serological recapitulation of childhood antibodies has received support from numerous observations, including those derived from prospective studies on the same persons (Schild and Stuart-Harris, 1965).

The serological effects on man of minor antigenic variations occurring in interpandemic periods have, however, received little attention. Zhdanov (1967) has attempted to predict the occurrence of epidemics by examining sera with different serotypes represented by viruses isolated recently and from less recent epidemics. In such work children's sera are likely to yield more definitive information than those of adults because of the relatively specific character of the antibody response in childhood. The success of the Russian method in predicting the 1965 epidemic of $A_{2}$ and the 1967 outbreak of $B$ influenza (Zhdanov et al., 1966; Zhdanov, 1967) indicates that it is 
worthy of wider exploration. Experience over prolonged periods of time will probably be necessary to assess its value. A start has been made on this in Sheffield by examining sera from children with recently isolated and serologically variant strains of influenza $A_{2}$ and $B$. The sera were collected at intervals from May 1965 onwards, and the period of study preceded and followed the mixed $\mathrm{A}_{2}$ and $\mathrm{B}$ influenza epidemic of January to March 1966.

\section{Materials and Methods}

Sera were obtained from the laboratories at the Children's and Royal Hospitals in Sheffield, either from patients in the wards or from specimens from children living in the Sheffield hospital region, and submitted for antistreptolysin $\mathrm{O}$ titres or blood-grouping. With the consent of their parents, 30 sera were obtained from healthy children attending a welfare clinic in the West Riding. Sera were stored frozen at $-20^{\circ} \mathrm{C}$. in screw-capped bottles.

Virus Strains.-The $A_{2}$ viruses were the prototype 1957 strain $A_{2} /$ Singapore $/ 1 / 57$, the $A_{2} /$ England/12/64 representative of the variants occurring in 1964-6 (Pereira et al., 1964), and $A_{2} /$ Czechoslovakia/1/66 isolated in December 1966 and kindly supplied by Dr. H. G. Pereira, of the World Influenza Centre in London. The influenza B viruses were B/Lee/1940, B/England/939/59, B/England/101/62, B/Taiwan/4/62, and $B /$ England $/ 13 / 65$. They were received from Dr. D. Hobson, of the University of Liverpool. B/Sheffield/66 was recovered in Sheffield in May 1966 from a patient with influenza. Pools of viruses were made by allantoic inoculation of 10-day embryonated eggs from stock cultures diluted $10^{-3}$ to $10^{-4}$. After incubation at $35^{\circ} \mathrm{C}$. for 48 hours the allantoic fluids were harvested, pooled, and stored frozen at $-70^{\circ} \mathrm{C}$.

Haemagglutination-inhibition Tests.-These were carried out in perspex trays by conventional methods (W.H.O., 1953), using 8 haemagglutinating units of virus and twofold serum
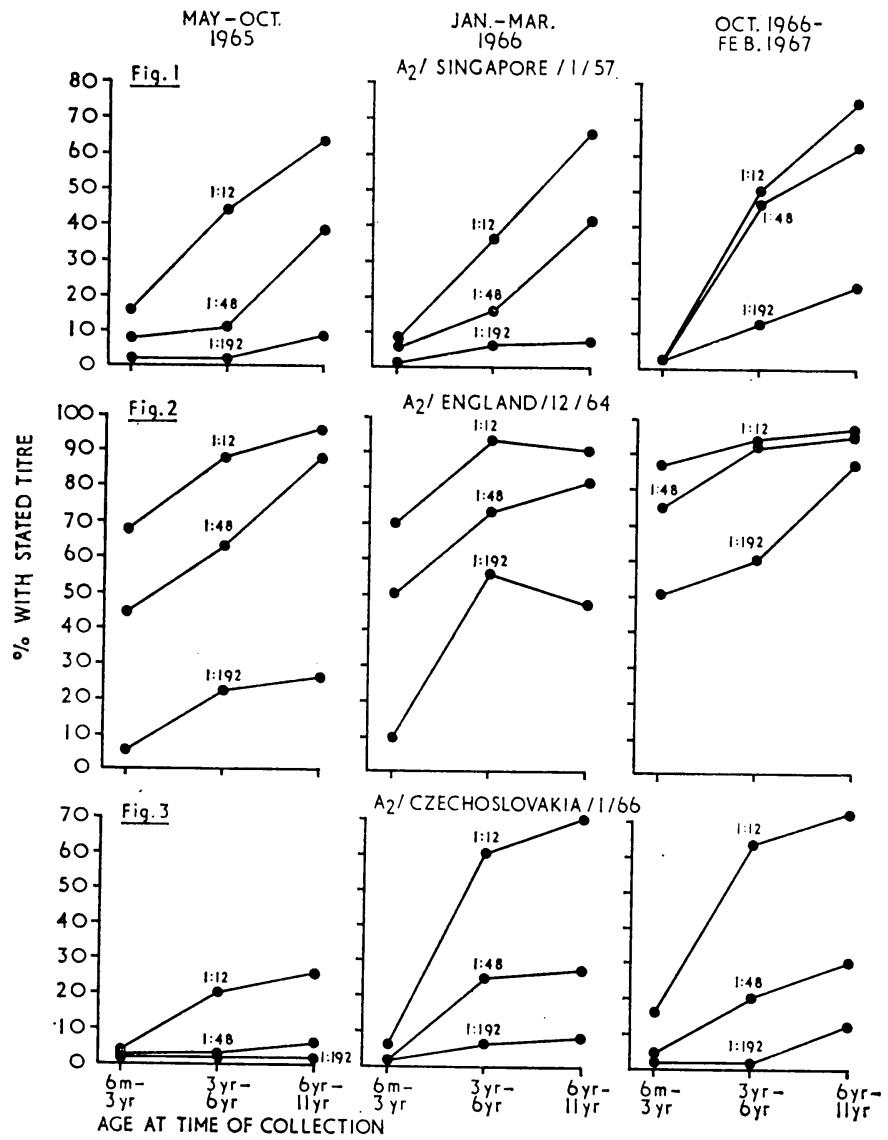

FIGS. 1-3.-Percentage of children of various ages with haemagglutination-inhibition antibody at the stated titre to influenza $A_{2}$ virus strains. dilutions. All sera were treated before test to remove nonspecific serum inhibitors by incubation overnight at $37^{\circ} \mathrm{C}$. with 5 vols. of cholera filtrate (N.V. Phillips Roxane or Burroughs Wellcome Ltd.). They were subsequently heated at $56^{\circ} \mathrm{C}$. for one hour to destroy the receptor-destroying enzyme.

\section{Results}

The ages of the children from whom the specimens were received varied from 6 months to 11 years at the time of collection. The serum collections were made in three periods-May to October 1965, January to March 1966, and October 1966 to February 1967. Not all the sera were tested against all the viruses, because of the actual volume of available serum. Figs. 1 to 7 show the proportion with antibodies for the appropriate viruses in each of these three serum collections. They represent at three titre levels the proportions with antibodies during and after the epidemic period $\left(A_{2}\right.$ and $\left.B\right)$ of 1966. Though the serum specimens came from different children in each of the three periods of time, the figures for each period show the percentage of sera with positive haemagglutinationinhibition at 1 in 12,1 in 48, and 1 in 192 dilutions. In each period of time the results from the children are shown at three separate ages of 6 months to 3 years, 3 to 6 years, and 6 to
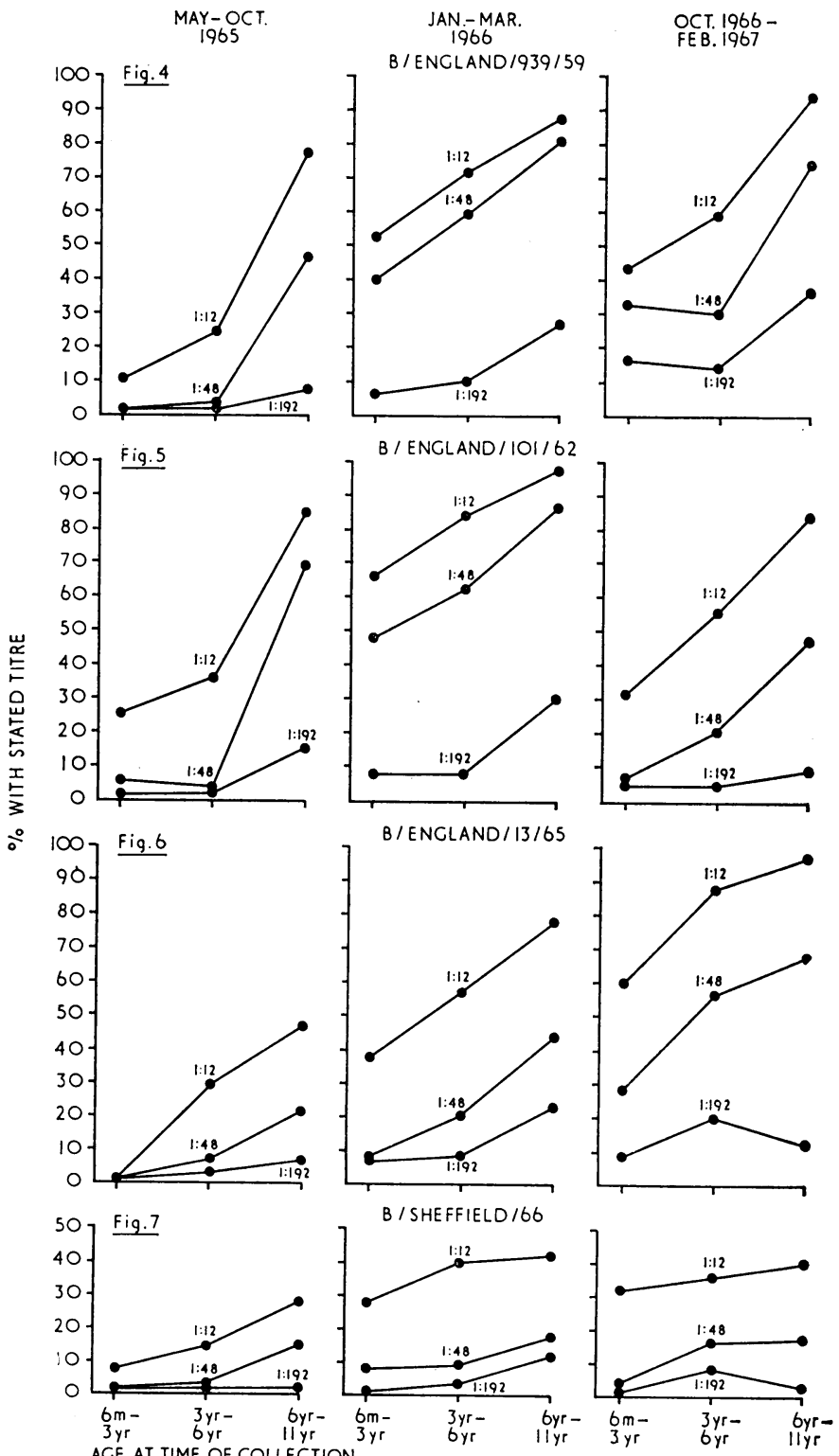

FIGS. 4-7.-Percentage of children of various ages with haemagglutination-inhibition antibody at the stated titre to influenza B virus straina. 
11 years at the time of collection. The relation between ages and dates of birth are shown in Table I.

TABLE I.-Range of Birth Dates of Serum Donors in the Various Age Groups of Children Studied

\begin{tabular}{|c|c|c|c|}
\hline \multirow{2}{*}{$\begin{array}{c}\text { Date } \\
\text { of Serum } \\
\text { Collection }\end{array}$} & \multicolumn{3}{|c|}{ Age of Donors at Time of Collection of Serum } \\
\hline & 6 Months-3 Years & 3-6 Years & $6-11$ Years \\
\hline $\begin{array}{l}\text { May-Oct. } 1965 \\
\text { Jan.-March } 1966 \\
\text { Oct. 1966-Feb. } 1967\end{array}$ & $\begin{array}{l}\text { May 1962-May } 1965^{*} \\
\text { Jan. 1962-Oct. } 1965 \\
\text { Oct. 1963-Sept. } 1966\end{array}$ & $\begin{array}{l}1959-62 \\
1959-62 \\
1960-3\end{array}$ & $\begin{array}{l}1954-9 \\
1954-9 \\
1955-60\end{array}$ \\
\hline
\end{tabular}

\section{$\mathbf{A}_{2}$ Virus Antibodies}

Table II and Figs. 1 to 3 show respectively the proportion of children with antibodies and the antibody distributions for the $A_{2}$ strains recovered in 1957, 1964, and 1966 and indicate definite differences in the results with the various viruses. Against the prototype $A_{2}$ virus shown in Fig. 1 there were relatively few differences between the various serum collections. The oldest children in each group who were alive during the earliest epidemics of the $A_{2}$ era in 1957 and 1959 show the greatest proportion of positive results (60 to 70\%) and the greatest number with high-titred sera $(10$ to $20 \%)$. Relatively few sera from the youngest children born from 1962 onwards gave positive results with the Singapore virus, and all of the sera from those born since October 1963 were negative. The 1966 epidemic appeared to have had little effect on the titre distributions except that the proportion of sera positive at a 1 in 48 dilution was greater in the most recent than in the earlier collections.

\begin{tabular}{|c|c|c|c|c|c|c|c|}
\hline \multirow{3}{*}{ Virus Strain } & \multirow{3}{*}{$\begin{array}{l}\text { Serum } \\
\text { Collections } \\
\text { and No. }\end{array}$} & \multicolumn{6}{|c|}{$\begin{array}{l}\text { No. and Proportion of Sera Inhibitory } \\
\text { at } 1 \text { in } 12 \text { Dilution or Higher }\end{array}$} \\
\hline & & \multicolumn{2}{|c|}{$\begin{array}{l}6 \text { Months- } \\
3 \text { Years }\end{array}$} & \multicolumn{2}{|c|}{6 Years } & \multicolumn{2}{|c|}{$11 \stackrel{6-}{\text { Years }}$} \\
\hline & & No. & $\%$ & No. & $\%$ & No. & $\%$ \\
\hline \multirow{3}{*}{$\mathrm{A}_{2} /$ Sing. $/ 57$} & May-Oct. 1965 & $7 / 45$ & 16 & $30 / 70$ & 43 & $35 / 65$ & 46 \\
\hline & Jan.-Mar. 1966 & $2 / 16$ & 12 & $13 / 34$ & 38 & $19 / 29$ & 66 \\
\hline & $\begin{array}{l}\text { Oct. } 1966-\text { Feb. } 1967 \\
(65)\end{array}$ & $0 / 14$ & 0 & $13 / 25$ & 52 & $20 / 26$ & 77 \\
\hline \multirow{3}{*}{$A_{2} /$ Eng. $/ 64$} & $\begin{array}{l}\text { May-Oct. } 1965 \\
\text { (180) }\end{array}$ & $31 / 45$ & 69 & $61 / 70$ & 87 & $62 / 65$ & 95 \\
\hline & $\begin{array}{l}\text { Jan.-Mar. } 1966 \\
(60)\end{array}$ & $9 / 13$ & 70 & $21 / 23$ & 96 & $21 / 24$ & 87 \\
\hline & $\begin{array}{l}\text { Oct. 1966-Feb. } 1967 \\
(65)\end{array}$ & $11 / 14$ & 78 & $23 / 25$ & 92 & $25 / 26$ & 95 \\
\hline \multirow{3}{*}{$\mathrm{A}_{3} / \mathrm{Czech} / 66$} & $\begin{array}{l}\text { May-Oct. } 1965 \\
\text { (120) }\end{array}$ & $1 / 30$ & 3 & $11 / 55$ & 20 & $9 / 35$ & 26 \\
\hline & $\begin{array}{l}\text { Jan.-Mar. } 1966 \\
(80)\end{array}$ & $1 / 15$ & 7 & $21 / 35$ & 60 & $21 / 30$ & 70 \\
\hline & $\begin{array}{l}\text { Oct. 1966-Feb. } 1967 \\
(65)\end{array}$ & $2 / 14$ & 14 & $16 / 25$ & 64 & $19 / 26$ & 73 \\
\hline
\end{tabular}

Antibodies against the $A_{2} / 64$ virus (Fig. 2) were present in a higher proportion of sera in all three periods and at higher dilutions than with the $A_{2} / 57$ virus. Indeed, the sera were so consistently inhibitory at 1 in 12 in all three collections that it is probable that $A_{2} / 64$ virus is more avid for antibody than $\mathrm{A}_{2} / 57$. The results obtained by Dr. H. G. Pereira with convalescent ferret sera (Table III) did not, however, suggest the existence of an undue avidity of the $A_{2} / 64$ virus, and the human results could also be explained on the basis of the cross-relationship of $A_{2} / 64$ with the $A_{2} / 57$ and $A_{2} / 66$ viruses, together with the effects of the 1964 and 1966 epidemics. Thus $85 \%$ of the sera from the oldest children (6 to 11 years of age) exhibited antibodies for $A_{2} / 64$ virus at 1 in 192 dilution in the 1966-7 collection; $50 \%$ of sera collected during January to March 1966 and only $25 \%$ of the 1965 sera were positive at 1 in 192 . An increase of high-titred sera against $A_{2} / 64$ virus also occurred in the groups of children under 3 years of age between the collection of sera early and later in 1966. These results probably indicate the effect of the outbreak of influenza in that year.
TABLE III.-Haemagglutination-inhibition Tests for Influenza $A_{2}$ Viruses with Immune Ferret Sera

\begin{tabular}{|c|c|c|c|}
\hline \multirow{2}{*}{ Virus Strains } & \multicolumn{3}{|c|}{ Sera } \\
\hline & $\mathrm{A}_{2} /$ Singapore $/ 1 / 57$ & $\mathrm{~A}_{2} /$ England $/ 12 / 64$ & $\mathrm{~A}_{2} /$ England $/ 1 / 66$ \\
\hline $\begin{array}{ll}\mathrm{A}_{2} / \text { Singapore/1/57 } & \ldots \\
\mathrm{A}_{2} / \text { England/12/64 } & \ldots \\
\mathrm{A}_{2} / \text { England } / 1 / 66 & \\
\mathrm{~A}_{2} / \text { Czechoslovakia/1/66 }\end{array}$ & $\begin{array}{r}2,560 \\
320 \\
240 \\
240\end{array}$ & $\begin{array}{r}160 \\
3,840 \\
960 \\
960\end{array}$ & $\begin{array}{r}160 \\
2,560 \\
1,920 \\
1,920\end{array}$ \\
\hline
\end{tabular}

The results with the $A_{2} / C z e c h / 1 / 66$ virus (Fig. 3) contrast with both the other $A_{2}$ viruses in that only a low percentage of the sera collected before January 1966 inhibited the virus. Even among the sera from the oldest children from the 1965 collection only $25 \%$ exhibited antibody demonstrable at 1 in 12 dilution, compared with $70 \%$ positive at the same dilution in both collections of sera from 1966 . This result was surprising in that tests with convalescent ferret sera (Table III) showed only slight antigenic differences between $\mathrm{A}_{2}$ /England/12/64 and $A_{2} / \mathrm{Czech} / 1 / 66$ viruses. Nor did they suggest that the latter strain was significantly non-avid in the haemagglutinationinhibition test. In addition, the titres obtained with the ferret antisera show that $A_{2} / \mathrm{Czech} / 66$ is serologically closely related to an $A_{2}$ virus $\left(A_{2} /\right.$ England $\left./ 1 / 66\right)$ isolated in Great Britain during the same year.

\section{Influenza B Viruses}

Antibodies were present in children's sera against each of the four B viruses isolated in England from 1959 to 1966 (Table IV), though the proportions and titres varied at different ages and in the different serum collections. Few sera contained demonstrable antibodies against the B/Lee/1940 and B/Taiwan/ $4 / 62$ strains. Those which did so react with these viruses were almost invariably from the oldest children among the several groups in whom 10 to $30 \%$ were positive at 1 in 12 . Such sera usually also possessed high antibody titres to the other influenza B strains, and particularly to B/England/13/65, thus suggesting that the antibodies to the Lee and Taiwan viruses were heterotypic and resulted from infection by the other B viruses.

Table IV indeed suggests that antibody orientated to $\mathrm{B} /$ Taiwan/62 might result from infection by the $1965 \mathrm{~B}$ viruses, for sera from ferrets convalescent from infection by the latter reacted also with the Taiwan strain. Similarly, crossreactions between $\mathrm{B} /$ England/59 and Lee ferret antisera, also shown in Table IV, would explain the presence of antibodies against the Lee virus in the sera from children exposed to infection in 1959. In regard to $B /$ England/65 and $B /$ England $/ 66$ viruses close serological resemblances were found by Dr. H. G. Pereira (personal communication). These results are borne out by the titres obtained in our own laboratory (Table IV).

TABLE IV.-Serological Relation Between Influenza B Virus Strains in

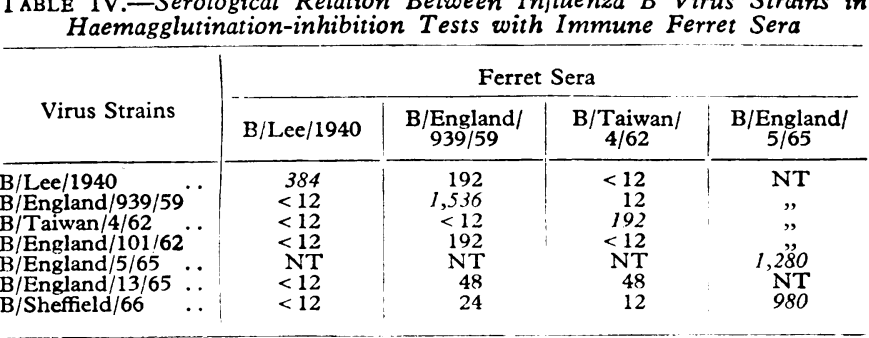

Table $\mathrm{V}$ and Figs. 4 to 7 give the human serological results with the viruses isolated in 1959, 1962, 1965, and 1966, all of which show in varying degree the effect of the $B$ outbreak in 1966. The fact that the older children, aged 6 to 11 years, exhibited higher titres than the infants in each group of sera is best explained by the repetitive effect of infection during the B epidemics in 1959 and 1962 on antibodies acquired before that date. The virus recovered in 1959 (Fig. 4) thus shows 
the effect of the 1966 epidemic in that an increased proportion of sera was positive in all three dilutions in the serum collections from 1966 compared with that from 1965. The older children exhibited both an increased proportion of sera positive at 1 in 12 in the latest compared with the earliest collection (from $80 \%$ in 1965 to $95 \%$ in 1966) and an increased number with higher titres.

TABLE V.-Antibodies to Influenza B Viruses

\begin{tabular}{|c|c|c|c|c|c|c|c|}
\hline \multirow{3}{*}{ Virus Strain } & \multirow{3}{*}{$\begin{array}{l}\text { Serum } \\
\text { Coilections } \\
\text { and No. }\end{array}$} & \multicolumn{6}{|c|}{$\begin{array}{l}\text { No. and Proportion of Sera Inhibitory } \\
\text { at } 1 \text { in } 12 \text { Dilution or Higher }\end{array}$} \\
\hline & & \multicolumn{2}{|c|}{$\begin{array}{l}6 \text { Months- } \\
3 \text { Years }\end{array}$} & \multicolumn{2}{|c|}{6 Years } & \multicolumn{2}{|c|}{11 Y- } \\
\hline & & No. & $\%$ & No. & $\%$ & No. & $\%$ \\
\hline \multirow{3}{*}{ B/Eng. 159} & May-Oct. 1965 & $3 / 30$ & 10 & $11 / 55$ & 20 & $27 / 35$ & 77 \\
\hline & $\underset{(85)}{\text { Jan.-Mar. } 1966}$ & $8 / 16$ & 50 & $29 / 39$ & 73 & $28 / 30$ & 93 \\
\hline & $\begin{array}{l}\text { Oct. 1966-Feb. } 1967 \\
(90)\end{array}$ & $7 / 18$ & 40 & $23 / 38$ & 60 & $32 / 34$ & 94 \\
\hline \multirow{3}{*}{ B/Eng./62 } & $\underset{(80)}{\text { May-Oct. } 1965}$ & $4 / 17$ & 24 & $13 / 35$ & 37 & $24 / 28$ & 86 \\
\hline & $\begin{array}{l}\text { Jan.-Mar. } 1966 \\
\text { (110) }\end{array}$ & $17 / 25$ & 68 & $42 / 50$ & 84 & $34 / 35$ & 97 \\
\hline & $\begin{array}{l}\text { Oct. 1966-Feb. } 1967 \\
(80)\end{array}$ & $6 / 18$ & 33 & $19 / 33$ & 58 & $24 / 29$ & 83 \\
\hline \multirow{3}{*}{ B/Eng. $/ 65$} & $\underset{(120)}{\text { May-Oct. } 1965}$ & $0 / 30$ & 0 & $16 / 55$ & 29 & $16 / 35$ & 46 \\
\hline & $\begin{array}{l}\text { Jan-Mar. } 1966 \\
\text { (110) }\end{array}$ & $10 / 25$ & 40 & $28 / 50$ & 56 & $27 / 35$ & 77 \\
\hline & $\begin{array}{l}\text { Oct. } 1966-\text { Feb. } 1967 \\
(90)\end{array}$ & $11 / 18$ & 60 & $33 / 38$ & 87 & $33 / 34$ & 97 \\
\hline \multirow{3}{*}{ B/Sheff./66 } & $\begin{array}{l}\text { May-Oct. } 1965 \\
(80)\end{array}$ & $1 / 17$ & 8 & $5 / 35$ & 14 & $8 / 28$ & 28 \\
\hline & $\begin{array}{l}\text { Jan-Mar. } 1966 \\
\text { (i10) }\end{array}$ & $7 / 25$ & 28 & $20 / 50$ & 40 & $15 / 35$ & 43 \\
\hline & $\begin{array}{l}\text { Oct. } 1966-\text { Feb. } 1967 \\
(80)\end{array}$ & $6 / 18$ & 33 & $11 / 33$ & 33 & $12 / 29$ & 40 \\
\hline
\end{tabular}

The pattern of antibodies against the $\mathrm{B} /$ England $/ 62$ virus (Fig. 5) was not greatly different from that obtained with the $\mathrm{B} / 59$ virus, as might be expected from the results with ferret antisera shown in Table IV. With the B/England/65 virus (Fig. 6) antibodies were not found in sera from the youngest children collected in 1965 but were present in $40 \%$ of sera from those aged less than 3 years collected in January to March 1966. Of the sera from the youngest children collected in $1966-7,60 \%$ were positive at 1 in 12 and $30 \%$ at 1 in 48 . The 1965 virus was thus inhibited by sera from the oldest children in all three collections, but a rise in both the proportion of inhibitory sera and in the number with strongly inhibitory properties occurred during 1966. The results with this virus are compatible with the view that the 1966 outbreak was associated with infection by a strain resembling B/England/ 65 , as was indicated also by the results with ferret antisera (Table IV).

However, the B virus recovered in Sheffield in 1966, which yielded results with ferret sera similar to those with both 1965 and other 1966 viruses, gave different results with the children's sera (Fig. 7). In the sera from $196528 \%$ of the oldest and less than $10 \%$ of the youngest children were inhibitory at 1 in 12 . Sera positive at 1 in 12 dilution formed from 30 to $40 \%$ at all ages of those collected during 1966. The 1966 outbreak thus appeared to have left the majority $(60 \%)$ of children, whose sera were collected from October 1966 onwards, with no antibodies at all to this virus (Table V). The youngest children in this group also exhibited an almost total lack of antibodies at 1 in 48 or higher, as in the case of the sera from children from 6 months to 6 years of age collected in 1965 .

\section{Discussion}

The purpose of this study was twofold. The first query was whether children's sera can be used to detect antigenic differences between recently isolated but serologically distinct virus strains. The results abundantly support the view that this is so. Indeed, children's sera appear to detect antigenic differences even more specifically than do sera from convalescent ferrets. The second purpose was to obtain baseline data concerning the effect of an outbreak of influenza on the distribution of antibodies in children of different ages. Such data might enable one to predict the likelihood of an outbreak. So far as the $A_{\text {, }}$ viruses are concerned, $A_{2} /$ England/ 64 was inhibited by a high proportion of sera collected before the 1966 outbreak, and therefore no indication would have been obtained with this strain of the imminence of an $A_{2}$ outbreak. Had the $A_{2} / 66$ variant been available, however, it would have revealed a low percentage (from 4 to 26 ) of children of all ages with antibodies in the pre-epidemic period. Thus the likelihood of an outbreak could have been foreseen, but probably only retrospectively, by using the epidemic strain.

In the case of the $B$ viruses the data show once again that there was a deficiency of antibodies in pre-epidemic sera against the virus which caused an outbreak in 1966. Yet, in spite of the known occurrence of localized outbreaks in the Januaryto-March period of that year, the $1965 \mathrm{~B}$ virus showed a similar deficiency of antibodies in the youngest children. Even in the case of children aged 3 to 6 years, only $29 \%$ exhibited antibody to the 1965 virus strain. On these grounds, therefore, the likelihood of a recurrence of infection by the 1965 virus or a related strain such as that actually experienced in $1966 \mathrm{might}$ have been considered probable.

It seems clear that further experience with sera from the youngest segment of the population other than those with maternal antibodies may give an indication of the likelihood of an outbreak if a very recently isolated antigenic variant is available. Much more experience will be necessary, however, before this method of prediction can be properly evaluated. For instance, a general lack of antibody to $B /$ Taiwan/4/62 virus existed in the children's sera. This strain, isolated in 1962 , was found at that time to be serologically distinct from previously known influenza B strains (Green et al., 1964). Yet it has never again been identified in an epidemic of influenza, a fact which indicates that not all antigenic variants of the influenza viruses are successful pathogenic agents even in the absence of serological immunity. Therefore the recovery of a new variant may not predicate the immediate likelihood of an outbreak of that virus.

\section{Summary}

A survey has been carried out on the incidence of haemagglutination-inhibiting antibody to influenza $A_{2}$ and $B$ virus strains isolated between 1957 and 1966 in sera collected from children aged 6 months to 11 years. Evidence of recent infection in the community with the various test viruses was indicated by changes in the frequency of occurrence of antibody in sera collected at different periods of time during the study. Serological differences were demonstrated between influenza virus strains even when the latter were closely related in tests with immune animal sera. The study provides baseline information on the effect of outbreaks of influenza on the distribution of antibodies in children's sera and raises the possibility of using such data in the prediction of future influenza epidemics.

We wish to thank Dr. H. G. Pereira, of the World Influenza Centre, London, for the provision of virus strains and immune animal sera and for helpful discussion. Dr. D. Hobson, of the University of Liverpool, kindly provided other virus strains. We are grateful for the excellent technical assistance of Miss $\mathrm{K}$. Cullen and Miss J. A. Waine.

REFERENCES

Davenport, F. M., Hennessy, A. V., and Francis, T., jun. (1953). F. exp. Med., 98, 641 .

Green, I. J., Hung, S. C., Yu, P. S., Lee, G. W., and Pereira, H. G. (1964). Amer. F. Hyg., 79, 107.

Pereira, H. G., Pereira, M. S., and Law, V. G. (1964). Bull. Wld Hlth Org., 31, 129.

Schild, G. C., and Stuart-Harris, C. H. (1965). 7. Hyg. (Lond.), 63, 479. World Health Organization (1953). Wld Hith Org. Tech. Rep. Ser., No. 64 .

Zhdanov, V. M. (1967). Lancet, 1, 263.

Nesterenko, M. K., Antonova, I. V., Gorbunova, A. S., Isacenko, V. A., and Krasovskaja, I. A. (1966). Bull. Wld Hlth Org., 34, 877. 